Article

\title{
Making Volunteering with Refugees Governable: The Contested Role of 'Civil Society' in the German Welcome Culture
}

\author{
Larissa Fleischmann \\ Department of Human Geography, Martin Luther University Halle-Wittenberg, 06120 Halle, Germany; \\ E-Mail: larissa.fleischmann@geo.uni-halle.de
}

Submitted: 17 January 2019 | Accepted: 13 March 2019 | Published: 27 June 2019

\begin{abstract}
This article investigates the manifold attempts of governmental actors to make volunteering with refugees governable in light of the so-called German Welcome Culture in 2015. Driven by the notion of a need to interfere, authorities introduced numerous programmes and efforts seeking to order, coordinate, influence, and enhance volunteering with refugees in order to make it more "effective". This investigation will suggest reading these interventions as attempts to (re)gain control and power over the conduct of committed citizens, making them complicit in the governance of asylum seekers, while co-opting potentially dissenting behaviour amongst them. Yet, it will also reveal how certain volunteers proved to contest their ascribed roles and responsibilities, demanding space for disagreement. Volunteering with refugees thus also constantly exceeded and defied governmental control and interference-and thereby remained, at least to a certain extent, ungovernable.
\end{abstract}

\section{Keywords}

civil society; civic solidarity; European refugee crisis; Germany; governance; humanitarianism; refugees; volunteering; Welcome Culture

Issue

This article is part of the issue "The European Refugee Controversy: Civil Solidarity, Cultural Imaginaries and Political Change", edited by Gert Verschraegen (University of Antwerp, Belgium) and Robin Vandevoordt (University of Oxford, UK/University of Antwerp, Belgium).

(C) 2019 by the author; licensee Cogitatio (Lisbon, Portugal). This article is licensed under a Creative Commons Attribution 4.0 International License (CC BY).

\section{Introduction: Volunteers as Protagonists in the Reception of Asylum Seekers}

This article contributes to ongoing discussions in the field of the anthropology of humanitarianism, investigating how ostensibly 'apolitical' humanitarian practices have become increasingly complicit in the governance of marginalized groups of society, such as irregular migrants and asylum seekers (Agier, 2010; Barnett, 2011; Bornstein \& Redfield, 2011; Fassin, 2007, 2011, 2012; Malkki, 1996, 2015; Rajaram, 2002; Ticktin, 2006, 2011, 2016). Building on 20 months of ethnographic fieldwork on volunteering with refugees in South-Western Germany between late 2014 and mid-2016, the following investigation provides insights into the ways in which governmental actors seek to gain influence and come to govern through domains commonly considered non- governmental. What is crucial here is that these insights will also illustrate how such attempts to govern only partially lead to their desired outcomes and remain continuously contested.

To elaborate these arguments in more detail, I focus on the developments that made history as an ostensible German Welcome Culture (cf. Hamann \& Karakayali, 2016; Heins \& Unrau, 2018; Karakayali, 2019; Sutter, 2019). The catchphrase depicts the extraordinary willingness of German residents to volunteer with refugees in the summer months of 2015, when the local reception of asylum seekers moved centre stage in public discussions across Germany. The media's accelerating attention with regards to the incidents at Europe's external borders as well as the notion of a humanitarian emergency situation mobilised many residents "to help", to become involved in volunteering activities in their neighbourhood, and 
to form self-organised citizens' initiatives in support of refugees in almost every corner of the country. Their activities were extraordinarily diverse and creative, including help in bureaucratic procedures, the sorting and distribution of donations, the organisation of joint leisure time activities, such as coffee rounds, joint gardening activities, handicraft circles, youth groups, or bicycle repair cafés. Moreover, volunteering with refugees spoke to a diverse group of people from various backgrounds and age groups, including many who had previously been neither committed socially nor politically (cf. Karakayali \& Kleist, 2016).

Governmental actors in the area of my field research in South-Western Germany highly appreciated this unforeseen increase in volunteering activities. As the following quote indicates, representatives from local to regional authorities regularly emphasised the value and significance of citizen commitment, acknowledging the volunteers' central role in the reception of asylum seekers:

You can't say it often enough to people who volunteer, what an important job they do. I always say this is the backbone of society if I can put it like that. If there wasn't such a willingness to volunteer, you wouldn't be able to run such a refugee reception facility. (Interview with a representative from a municipality in Southern Germany, March 2016; emphasis added)

Quite connectedly, many of the volunteers I spoke with presented their actions as complementary to local governmental efforts in accommodating asylum seekers on the ground. Many also demarcated their actions from what they perceived to be forms of left-wing political activism for the sake of refugees and asylum seekers. In contrast to such political forms of acting, they depicted their volunteering activities as an 'apolitical' ${ }^{1}$ humanitarian duty to those who are suffering, claiming that they "just wanted to help" (see Fleischmann \& Steinhilper, 2017; Hamann \& Karakayali, 2016; Vandevoordt \& Verschraegen, 2019).

These meaning-making processes point to the entangled and complicit role of volunteering and the governing of asylum seekers, which sometimes also share a coconstitutive relationship. The "proper" nature of this relationship, however, remained highly contested during the German migration summer and subject to continuous negotiations between governmental actors on the one hand and volunteers on the other. As I realized during my ethnographic fieldwork, some of the new volunteers also continuously exceeded and defied governmental objectives in the management of asylum seekers. It is thus central to stress the ambiguous meanings and effects of volunteering with refugees at the outset of this investigation, acknowledging how volunteering also came with quite political and dissenting potential despite its humanitarian motivation (cf. Fleischmann, 2017; Pries, 2019; Vandevoordt \& Verschraegen, 2019). Moreover, rather than constituting a homogenous group, volunteering activities brought together a wide range of individuals whose position could also change over time with possibilities for politicisation emerging through commitment. For instance, those who started with ostensibly 'apolitical' humanitarian motivations might have turned gradually more political when experiencing injustices and fault lines in asylum laws and policies, eventually not hesitating to counteract governmental policies.

The German summer of migration thus brought about important-but necessarily contested-(re)negotiations of the role and responsibilities of "active citizens" vis-à-vis "the state" in migration societies. Here, I am particularly interested in the question of how governmental actors sought to make volunteering with refugees governable, while attempting to regain sovereign power in the management of asylum seekers. ${ }^{2}$ I ask for the mechanisms and patterns with which they aimed to shape the "proper" conduct of volunteering, for instance, through the introduction of numerous programmes and efforts seeking to influence, enhance, or coordinate volunteering activities on the ground. Such efforts unfolded prominently on sub-national levels of government, i.e. in municipal authorities and state governments. ${ }^{3}$ Although similar developments might have taken shape at the federal government, I focus on the regional and local levels here, since they appeared to have a more immediate influence on the volunteers' activities in the area of my field research.

I structured this article into five sections. In Section 2, I scrutinise how "civil society" emerged as a field of governmental interference through manifold programmes introduced in the area of my field research in the course

\footnotetext{
$\overline{1}$ I put the term 'apolitical' in single quotation marks throughout this text in order to highlight that I distance myself from such 'apolitical' self- and other-depictions, which I encountered during field research. Analytically, I believe that apolitical claims in relation to the topic of migration and asylum are impossible to implement in practice. Nevertheless, an 'apolitical' claim can have quite ambiguous political effects (cf. Redfield, 2011). I thus suggest that it is rather much more fruitful to distinguish analytically between anti-political and political forms of action, whereby the former stands for the reinforcement of exclusions in a given order, while the latter depicts the enactment of more inclusive alternatives (cf. Rancière, 1998, 2001; Ticktin, 2011).

2 I understand sovereign power as the ability to decide upon inclusion and exclusion-a reading that is inspired by the works of Giorgio Agamben (Agamben, 1998, 2000, 2005). In the governance of migration, sovereign power unfolds in the incentive to order migration flows into neat categories of victims and villains of migration, while drawing a neat demarcation line between those who become the 'rightful' subjects of protection and those who are excluded, marginalised, and rendered deportable.

${ }^{3}$ My fieldwork focussed particularly on the state of Baden-Württemberg, one of the 16 German states located in South-Western Germany. Consequently, my field research took place within a specific political climate that appeared to put citizen engagement high on the agenda. Baden-Württemberg held the only state government throughout Germany that joined a coalition of the Greens and the Social Democratic Party (SPD). Right from the start of its legislative period, the ruling government declared the enhancement of citizen engagement to be one of its top priorities. The insights I provide throughout this article are therefore not only contingent on the particular political but also historical, regional, and socioeconomic context of this specific part of Germany, meaning that my findings might not, or only partly, be transferable to other regions of the country.
} 
of 2015. In Section 3, I argue that, in this process, responsibilities became (re)ordered between "state" and "civil society", while governmental actors increasingly sought to govern the self-conduct of committed citizens-yet, not always and necessarily with their intended outcomes. Section 4 then investigates how governmental actors dealt with dissenting volunteers through acts of co-optation, attempting to make them complicit in the management of asylum seekers. In Section 5, I wrap up with a concluding discussion of the (un)governability of volunteering with refugees during the German summer of migration.

\section{Making 'Civil Society' a Field of Governmental Intervention}

When this big issue of helping refugees emerged, they [the state government] obviously said we need to make sure that municipalities intervene in a coordinating capacity. Citizen engagement always needs professional coordination, professional partners. At the moment, there is nowhere near enough manpower behind it....We can help there, we thought, set up a good support programme, so we set up our support programme. (Interview with a Deputy Secretary in the state government of Baden-Württemberg, April 2016)

In light of the fast-growing numbers of volunteers, governmental actors and public authorities in the area of my field research felt a growing "need to intervene" in order to coordinate, enhance, support, or manage volunteering activities in their area of influence. For instance, the government of the South-Western German state of Baden-Württemberg introduced numerous programmes targeting volunteers across the state. The design and circulation of a free practical guidebook entitled Welcome! A Handbook for Voluntary Help for Refugees in BadenWürttemberg (Staatsministerium-BW, 2015) was a striking case in point. Published by the state government of Baden-Württemberg, it featured examples of good practice as well as practical information and advice for newly committed volunteers. As one of my interlocutors, a member of the Green state government told me, the booklet presented a "complete success" with more than 30,000 free copies given out within a few weeks after its publication. Alongside this booklet, the state government introduced numerous other incentives seeking to influence volunteering practices, such as special training schemes for newly committed citizens, financial support programmes, regular conferences aiming to facilitate dialogue and networking among governmental representatives and volunteers, the publication of a regular newsletter dedicated to volunteers, or a website featuring prac- tical information and examples of good practice. It was the claim that volunteering with refugees required guidance, coordination, and support in order to work effectively that underpinned these manifold efforts.

The notion of a need to intervene also triggered changes on a more local level. For instance, municipalities and district councils across the area of my field research employed so-called "Volunteer Coordinators", stating that volunteers were in need of professionals in order to work effectively. These newly appointed representatives served as a primary contact for citizens willing to volunteer with refugees on the ground. They assigned tasks to prospective volunteers, coordinated their activities and constituted a link with public authorities. A similar development to employ Volunteer Coordinators took hold in social welfare organisations, which received increased funding from the state government in order to do so.

These manifold governmental programmes on the local and regional level led to the institutionalisation of citizen commitment as part and parcel of the management of asylum seekers. It was in this context, so to speak, that an entity imagined as "civil society" was born as a responsible actor in the reception of asylum seekers. ${ }^{4}$ This began in late 2014 when the state cabinet of BadenWürttemberg decided to allocate substantial funding for the development of programmes targeted at volunteering with refugees. Before that point in time, the state government had not implemented any incentives to intervene in volunteering with refugees, indicating that it did not consider volunteers to play a central role in the reception and integration of asylum seekers. This came through very clearly during my interview with a Deputy Secretary responsible for citizen engagement on the level of the state government. She claimed that the design and implementation of programmes directed at volunteering with refugees resembled a "process of invention". She explained this as follows:

Citizen commitment [with refugees] is something that didn't really exist before. So, we didn't have a support programme or such like.... It's just down to what's happening in society that we are now paying so much attention to the refugee issue and that we have launched a dedicated programme. (Interview with a Deputy Secretary in the state government of BadenWürttemberg, April 2016)

My interlocutor, speaking from the perspective of the state government, thus claimed that citizen commitment with refugees "didn't really exist before". However, during my field research, I encountered groups and individuals who had actually been supporting refugees for decades, often with humanitarian or faith-based motivations. Moreover, decidedly leftist political activists had

\footnotetext{
${ }^{4}$ Here, I refer particularly to the segment of "civil society" that is concerned with refugees and asylum seekers and that is understood as being constituted by "ordinary" citizens who commit themselves for the public good. I claim that such a function of "civil society" only became known to governmental actors and institutionalised as an actor with certain responsibilities from late 2014 onwards. Beyond this specific contextual meaning, however, it is important to note that "civil society" holds a historically important role in Germany (cf. Keane, 2006; Nützenadel \& Strupp, 2007).
} 
fought for the rights of refugees and asylum seekers long before the reception of asylum seekers moved to the centre of public attention from late 2014 onwards (see Atac, Kron, \& Stierl, 2015). And yet, as the quote above suggests, "civil society" only became visible for the state government of Baden-Württemberg when an unprecedented and extraordinary increase in people willing to commit themselves for the sake of refugees unfolded.

The newly introduced governmental programmes thus constituted a section of "civil society" concerning itself with refugees as an actor with certain responsibilities. This observation connects with academic works pointing to the entangled and co-constitutive nature of understandings of "civil society" vis-à-vis "the state" (see for instance Ferguson \& Gupta, 2002). Rather than regarding "civil society" as an entity that is meaningful in itself, it is thus central to investigate the contested rationalities, mechanisms, and practices that produce a certain understanding of the role of "civil society" vis-à-vis "the state", while ordering responsibilities between the two. As Baker-Cristales (2008, p. 352) puts that aptly: "Civil society does not exist as a prior and primordial unit; rather, civil society is formed in and through the same discourses and practices that create that artificially bounded postulate, the state". Mitchell (1991), on the other hand, calls attention to the contested processes of boundary-making between what appear to be two distinct entities; processes that he understands as mechanisms through which power is generated and a given social and political order maintained (Mitchell, 1991, p. 90).

Taking my cue from such works, I would suggest that the governmental efforts to intervene on volunteering served as a means to (re)gain control and power over both the management of asylum seekers as well as the growing numbers of volunteers committed to refugees. This came through very clearly in an interview with a Green member of the state government of BadenWürttemberg in charge of the programmes targeting volunteers across the state. She told me that she and her colleagues would strive to promote "effective volunteering", i.e., volunteering that is supervised and guided by those professionally employed in the reception of asylum seekers. Volunteering without professional guidance and coordination, on the other hand, often became associated with "chaos" and "disorder" being due to the extraordinary and sudden explosion of volunteering activities in 2015. Scholars in the field of critical migration studies argue that such notions of "chaos" and "crisis" in relation to the topic of migration serve as a powerful legitimisation strategy for state actors to exert control and power (Coleman, 2007; Mountz, 2011; Mountz \& Hiemstra, 2014). A similar point tendency unfolds in the incentive to "order" and "coordinate" volunteering activities around the long summer of migration: the notion of disorder legitimised governmental interventions seeking to (re)gain control and power over committed citizens.

To sum up, volunteering with refugees emerged as an important site of governmental intervention in the course of Germany's migration summer. This development also laid the ground for a (re)ordering of tasks and responsibilities between "the state" and "civil society" a (re)ordering that nevertheless remained highly contested and subject to different negotiations. In the following section, I will sketch out some patterns of these (re)ordering processes in more detail.

\section{3. (Re)ordering Responsibilities in the Reception of Asylum Seekers}

A key objective for governmental actors to intervene in volunteering with refugees was the meaningful division of responsibilities between "state" and "civil society". Only if "the state" and "civil society" were willing to act in concert and to collaborate for a joint purpose, my interlocutors stated, they could achieve a smooth reception and integration of asylum seekers. The incentive for harmonious collaboration and synergy not only underpinned the newly introduced governmental programmes but also came with an emphasis on humanitarian benevolence for those who are suffering. This observation connects with academic works in social anthropology and beyond, outlining how, through an emphasis on care and compassion, ostensibly non-governmental humanitarian actors become complicit in the governance of migration (Fassin, 2007; Walters, 2011). For instance, Ticktin (2011) emphasises how civil society actors increasingly took up tasks and responsibilities in the governance of (irregular) migrants in France and thereby formed part of, what she calls, a "regime of care" spanning both state and civil society actors. According to Nyers (2006), such complicity might result in forms of "humanitarian violence" that occur when humanitarian and governmental actors work in perfect synergy. In line with these works, I would argue that governmental actors in the area of my field research sought to manage the rising numbers of asylum seekers in Germany's migration summer through extended statecitizens networks that placed an emphasis on humanitarian help and compassion.

The emphasis on a meaningful division of tasks that underpinned governmental interventions on volunteering thus allocated responsibilities to 'civil society' deemed beneficial to the management of migration. While governmental representatives in the area of my field research often asserted that "the state" is responsible for more "technical matters" in the reception of asylum seekers, such as the provision of accommodation, the passing of legislation, or political decisionmaking processes, they portrayed "civil society" as essential for the "soft factors" of integration, such as "feeling welcome" or building bridges between refugees and the host society. As a delegate of the state government of Baden-Württemberg once told me, a key task of "civil society" was to produce "acceptance" for both asylum seekers and governmental decisions relating to their reception. Such images clearly depicted "the state" as being the one who determines the key tenets of mi- 
gration management "from above", while "civil society" was responsible for effectuating these decisions "on the ground". According to Ferguson and Gupta (2002, p. 982), such spatial metaphors of verticality serve as a means for "the state" to reify itself as an enclosed entity while legitimatising its power and authority over "civil society", portraying itself as being "located above". Quite connectedly, governmental incentives to ensure a "meaningful" division of tasks and responsibilities in the area of my field research simultaneously (re)produced "the state" as being the legitimate source of power and authority in the management of asylum seekers.

The tendency to (re)order certain responsibilities to the level of committed citizens also chimes in with what scholars, taking their cue from Foucault's works on governmentality (Foucault, 1982, 1988), identified as wider shifts in techniques of governing. For instance, Lessenich (2011, p. 304) argues that social responsibility for the public good is increasingly being transferred from the level of "the state" to the level of individual citizens who become "the bearers not of social rights, but of social obligations". Lemke (2002) also points at a more profound shift in recent techniques of governing, which he describes as follows:

What we observe today is...a displacement from formal to informal techniques of government and the appearance of new actors on the scene of government (e.g. NGOs) that indicate a fundamental transformation in statehood and a new relation between state and civil society actors. (Lemke, 2002, p. 11)

Others thus propose turning attention to the practices by which our own conduct is shaped (Dean, 1996, 2010; Rose, 1996). Yet, it is important to counterbalance such arguments identifying a tectonic shift in the relationship between "state" and "civil society" through a recognition of the historically important role of active citizens in German state policies (see for instance Keane, 2006). Either way, I would suggest that the manifold governmental programmes targeting volunteering with refugees from 2015 onwards presented renewed opportunities for governmental actors to promote and actualise "responsible citizens" and, ultimately, to govern (through) their citizen-subjects.

In the area of my field research, such attempts to allocate certain responsibilities to active citizens manifested themselves in various efforts to influence the "proper" self-conduct of volunteers on the ground. The introduction of countless training schemes directed at (prospective) volunteers was a striking case in point. Such training schemes built on the notion that volunteers needed qualification and education in order to work effectively, hence putting an emphasis on self-improvement and selfconduct. The state government of Baden-Württemberg allocated millions of Euros for the implementation of a dedicated training programme for volunteers across the state, entitled "Qualified Engaged". Municipalities across the area of my field research implemented workshops and seminars seeking to educate citizens on how to volunteer "properly", i.e., in a manner that served their interests in the local administration and management of asylum seekers. A similar attempt to shape the (self-)conduct of committed citizens became manifested in the publication of a guidebook, as well as a website featuring examples of "best practices". It also unfolded in the employment of numerous Volunteer Coordinators in municipalities across the area of my field research. As I realised in the course of my field research, they were often in a quite powerful position, acting as gatekeepers to information, funding, and reception facilities. They were able to exert considerable influence on volunteers under their guidance. For instance, they determined the tasks to be assigned to newly committed volunteers, thus shaping the nature of volunteering activities on the ground, while seeking to prevent forms of volunteering that were rated as unbeneficial. These diverse efforts to intervene in volunteering on the ground, I would argue, normalised a certain way of acting and being in relation to the public good while producing volunteers as "responsible citizens" within "the state".

The governmental attempts to (re)order certain responsibilities and to influence the self-conduct of committed citizens, however, did not necessarily lead to their intended outcomes. Certain volunteers continuously contested these interferences. In the course of my field research, I came across numerous moments when they openly criticised and voiced dissent at efforts to coordinate, influence, and shape their volunteering activities on the ground. For instance, numerous volunteers told me that they felt patronised by professionals, such as Volunteer Coordinators, who sought to get hold of their activities on the ground. I also witnessed controversial discussions among them concerning the perceived mushrooming of training schemes offered by governmental actors. This clearly came across during my observations at the regular conventions of the Refugee Council. This non-governmental organisation functions as an umbrella association for local citizens' initiatives in support of refugees at the level of the state, lobbies for their concerns at the level of state politics and constitutes an independent source of information and exchange for many of the volunteers. As I realised in the course of my field research, the Refugee Council's regular conventions also served as an important platform for volunteers, where they discussed controversial matters and elaborated positions in regards to the governmental handling of asylum seekers.

During the introductory address to a convention I attended in November 2015, the present volunteers reflected critically on "attempts by local administrations to intervene in volunteering". Eventually, a heated debate evolved with the volunteers voicing substantial dissent over attempts to coordinate their voluntary workattempts that they clearly perceived as an affront to their independence. Quite strikingly, a volunteer in the audi- 
ence stepped up asserting that through governmental interventions on volunteering, "only agreeable activities are promoted while others are hindered". These findings connect with what a study of the Berlin Institute for Integration and Migration Research (BIM, 2018, p. 10) illustrates concerning the increased provision of funding schemes for initiatives in support of refugees. Accordingly, more than a third of those interviewed claimed to be striving to remain "independent", meaning that they did not want to become dependent on municipal administrations through the acceptance of certain funding opportunities.

On another occasion, in March 2015, a likely heated debate evolved concerning the governments' implementation of numerous training schemes targeting those who set out to volunteer with refugees. According to the audience members, such seminars would often focus merely on the practical aspects of helping, while local authorities would strategically hinder education on asylum politics and asylum law - a matter where volunteers truly needed training. Eventually, a leading member of the Refugee Council stepped up announcing that "the decision as to who trains whom should be made first and foremost by volunteers themselves", a statement for which she gained a standing ovation from the audience.

These anecdotes from my field research indicate that the intensified governmental efforts to intervene on volunteering with refugees also came with quite unintended consequences: they opened up possibilities for politicisation and disagreement among those active for the sake of refugees. The scrutinized moments of dissent that I encountered during field research aptly how some of the volunteers also defied or even challenged governmental interferences on their responsibility and selfconduct, instead of merely becoming silent accomplices in the governance of migration. Clearly, thus, volunteering with refugees not only constituted a field of governmental intervention but also opened up possibilities for resistance, opposition, and politicisation. It therefore comes as no surprise that governmental interventions also came with attempts to deal with and prevent those more 'unruly' aspects of volunteering with refugees.

\section{Dealing with Unruly Volunteers}

Alongside their emphasis on smooth cooperation, governmental interventions on volunteering also came with attempts to limit the space for disagreement between what they depicted as "the state" and "civil society". As I outlined in the previous section, governmental actors expected "civil society" to complement their efforts in the governance of asylum seekers meaningfully and to produce acceptance for their decisions. Such a reading of the role and responsibility of "civil society", however, silenced the possibility for non-governmental actors to also intervene critically, to demand legal and political reforms, to voice dissent at governmental actors, to protest governmental decisions, or to point at deficiencies in the workings of "the state". Yet, as noted in the introduction to this article, the manifold practices in support of refugees that emerged around the so-called European refugee crisis also encompassed such more subversive potentials. Furthermore, as the short anecdotes from my fieldwork provided in the preceding section indicate, citizens themselves (re)negotiated their ascribed role in the reception of asylum seekers, which sometimes substantially departed from what governmental actors had intended.

Nevertheless, governmental interventions on volunteering with refugees in the area of my field research often denied the volunteers' scope for dissent. In an interview with a deputy at the state government of BadenWürttemberg, my interlocutor classified these more critical forms of civic solidarity with refugees as "uncomfortable engagement". Our conversation also strikingly revealed how governmental representatives in the area of my field research often drew a straight boundary line between volunteering with refugees, on the one hand, and forms of political campaigning and protest on the other, attempting to keep the both of them neatly separated. Only activities subsumed in the former of these two categorisations, seen as being located at the less confrontational and more "constructive" end, were presented as worthy of governmental promotion by my interlocutor. To be clear, as indicated earlier, the diverse forms of supporting refugees that developed in Germany's migration summer constantly exceeded such a neat distinction between ostensibly 'apolitical' volunteering and common understandings of political activism, coming with subversive potentials despite their claim to remain 'apolitical'. There were countless moments when volunteers explicitly demanded the possibility to participate in political decision-making processes and, if need be, to also contest local authorities' handling of asylum seekers. This came through, for instance, in an interview with the head of a citizens' initiative in the area of my field research who recounted his frustration with the local authorities' lack of consultation:

If the council says, "we need volunteers for our work", then, in my opinion, they also have to consult them on decisions and include them to a certain extent...they should at least say, "hey, what do you think? Are you okay with that", and if we have objections, then we have to try and find a course that both parties can live with. (Interview with a volunteer, April 2016)

The perception of a lack of space for disagreement with governmental actors, I would argue, even presented one of the top sources resulting in frustration among the volunteers.

Governmental actors in the area of my field research also worked directly towards the prevention or cooptation of such potentials for disagreement and critique emanating from the volunteers. Following Coy (2013), I understand co-optation as a means of extending governmental power over potential dissenters within society: 
Those in authority who are being challenged may reach out to, and attempt to bring the challengers into the system as participants. This formalised inclusion of challengers into the authority system that they are challenging is the essence of co-optation. (Coy, 2013)

The newly established positions of Volunteer Coordinators played an important role in such attempts of cooptation. As mentioned earlier, they were often in quite a powerful position by assigning tasks and determining the nature and extent of volunteering activities on the ground. This also allowed them to cushion potentials for more "uncomfortable" forms of commitment among the volunteers under their supervision. For instance, in a conversation with a local Volunteer Coordinator, I asked her if she had come across instances when volunteers under her guidance set out to voice discontent with the local management of asylum seekers, for instance in the local press. She denied, replying that her "boss" - who happened to be the mayor of the respective town- "would not like this at all". As this example illustrates, Volunteer Coordinators across the area of my field research often appeared to serve as extended arms of local authorities, exerting influence over the 'proper' conduct of committed citizens on the ground, while preventing forms of dissent and potentials for protest. This also came through in an interview with another Volunteer Coordinator in the area of my field research who told me rather openly that it was her job to intervene directly when volunteers did not comply with the "rules". Accordingly, she felt responsible for dealing with those volunteers who would show "problematic" or "deviant" behaviour. She asserted that there were some who would not know "their limits", who would reject the tasks assigned to them, or who would get "too involved" by building overly emotional ties to certain asylum seekers. If she would notice such behaviour, indicating that volunteers suffered from a "helper syndrome", my interlocutor would then immediately schedule an appointment with the affected, asking them to reduce their commitment. This points to a certain pathologisation of the behaviour that the Volunteer Coordinator classified as detrimental. Her disciplining interventions, I would suggest, might have aimed at preventing overly close and personal relationships with asylum seekers, since they could potentially result in the rejection of deportation orders and thus dissenting actions among the volunteers. This aptly indicates how the newly appointed Volunteer Coordinators played an important role in attempts to co-opt certain forms of volunteering and to cushion potentials resulting in uncomfortable situations for governmental actors. And yet, such attempts of co-optation did not always result in their desired outcomes. While some of the volunteers might have been frustrated and dropped out in response to such disciplining interventions, others might have become politicised, joining other groups with a more explicitly political or independent self-understanding.
It was the issue of deportation that most clearly illustrated how governmental actors strived for the cooptation of dissenting potentials among the volunteers. Various scholars in the field of critical migration studies point at the political significance of struggles over deportations (see, for instance, Darling, 2014; De Genova, 2010). Peter Nyers $(2010$, p. 415) suggests that they might be "read in terms of contemporary disputes over who has the authority to protect, and under what terms and conditions". In this light, the enforcement of deportation orders holds an important strategic function for "the state" in that it serves as a means to reinforce sovereign power (cf. Ilcan, 2014). Tyler and Marciniak (2013, p. 145), for instance, argue that the risk of being deported functions as an important source of domination and power in the governance of migration. It is no surprise then, that governmental actors in the area of my field research expected committed citizens to accept such decisions uncritically, rather than contesting or hindering them. Despite these governmental expectations, however, volunteers regularly considered certain deportation orders as unjust, voiced dissent and engaged in acts of protest. Some did not even hesitate to challenge deportation orders legally, block them directly, hide respective asylum seekers in their houses, or apply for church asylum as a means to circumvent actual deportations.

Consequently, though, governmental representatives regularly sought to impede such possibilities for politicisation in relation to deportation orders among the volunteers. They did so by emphasising that the "proper" way for committed citizens to respond to deportation orders was to provide advice on how to return successfully to the asylum seekers' country of origin. This came through very clearly when I attended a conference for volunteers held by the state government of Baden-Württemberg in March 2015. Several speakers at the conference, mostly governmental representatives, emphasised that-along with efforts to integrate accepted refugees-"qualified returnee counselling" was an "equally important" responsibility for committed citizens. Vandevoordt (2016) identifies a quite similar tendency with reference to Belgium. He illustrates how, through the promotion of a voluntary return to the migrants' country of origin, governmental actors make civil society actors complicit in the management of asylum seekers. Connectedly, I would argue that through their emphasis on such "returnee counselling", governmental actors in the area of my field research sought to make volunteers complicit in the governance of migration, while co-opting potentially dissenting behaviour among them. By doing so, they left no space for disagreement but rather claimed that committed citizens had to uncritically accept and complement governmental decisions in the management of asylum seekers. Yet, with partial success, the question of how volunteers were to position themselves and react in relation to deportation orders deemed unjust proved to remain one of the most controversially discussed topic among the volunteers them- 
selves. While some did not want to engage in any sort of such critical or "unruly" behaviour, others considered it a key responsibility of 'civil society' to speak out against witnessed injustices in the context of deportation orders.

\section{Concluding Discussion: The (Un)Governability of Volunteering with Refugees}

This article investigated how governmental actors intervened in order to make volunteering with refugees governable. It argued that it was in the context of an ostensible German Welcome Culture that "civil society" emerged as a responsible actor in the governance of asylum seekers. Through the introduction of numerous programmes and efforts, local to regional authorities in the area of my field research (re)ordered responsibilities with regards to the reception of asylum seekers and intervened on the (self-)conduct of committed citizens, making them complicit in the management of asylum seekers while seeking to govern through "responsible citizens".

On the one hand, these attempts to govern volunteers result in a substantially limited scope for 'civil society' to act independently from governmental objectives, to bring about political change and transformation, or to take a stand in relation to witnessed injustices in the management of asylum seekers. The findings of this article might thus support Muehlebach's argument that "the state, while withdrawing its welfarist functions, mediates its own withdrawal by mobilising thousands of volunteers into caring about, and for, the less fortunate" (2013, p. 454). This might come with problematic consequences for those who are seeking asylum: rather than the bearers of rights and legal entitlements, they become the recipients of generous help and humanitarian benevolence (cf. Fassin, 2016).

On the other hand, however, governmental efforts to intervene do not always lead to their intended outcomes. Certain volunteers challenge assumptions on their "right" conduct and (re)negotiate the role of "civil society" in relation to the reception of asylum seekers, demanding scope for dissent, disagreement and independence. By doing so, they prove to remain "unruly", defying governmental attempts to interfere on their conduct. The shifting yet contested readings of the role of "civil society" during Germany's migration summer, I would suggest, thus also opened up new avenues for forms of civic solidarity with refugees to induce change and transformation towards more egalitarian alternatives. The soaring governmental appreciation of volunteers, as well as the increased acknowledgement of their role and responsibility, temporarily shifted power and agency over to committed citizens, some of whom will always remain to a certain extent ungovernable.

\section{Acknowledgments}

The author would like to thank the Martin Luther University Open Access Fund for its financial support for this publication. The research for this article was made possible with the financial and intellectual support of the Centre of Excellence "Social Foundations of Cultural Integration" as well as the Department for Social and Cultural Anthropology headed by Prof. Thomas G. Kirsch at the University of Konstanz.

\section{Conflict of Interests}

The author declares no conflict of interests.

\section{References}

Agamben, G. (1998). Homo sacer: Sovereign power and bare life. Stanford, CA: Stanford University Press.

Agamben, G. (2000). Means without end: Notes on politics (Vol. 20). Minneapolis, MN: University of Minnesota Press.

Agamben, G. (2005). State of exception. Chicago, IL: The University of Chicago Press.

Agier, M. (2010). Humanity as an identity and its political effects (a note on camps and humanitarian government). Humanity: An International Journal of Human Rights, Humanitarianism, and Development, 1(1), 29-45.

Atac, I., Kron, S., \& Stierl, M. (2015). Kämpfe der Migration als Un-/Sichtbare Politiken. Einleitung zur zweiten Ausgabe [Struggles of migration as in-/visible politics. Introduction to the second issue]. Movements. Journal für kritische Migrations- und Grenzregimeforschung, 1(2).

Baker-Cristales, B. (2008). Magical pursuits: Legitimacy and representation in a transnational political field. American Anthropologist, 110(3), 349-359.

Barnett, M. N. (2011). Empire of humanity: A history of humanitarianism. Ithaca, NY: Cornell University Press.

BIM. (2018). Fördermittel in der Flüchtlingshilfe. Was gebraucht wird-was ankommt [Funding schemes in the voluntary help for refugees. What is neededand what is well received]. Gütersloh: Bertelsmann Stiftung.

Bornstein, E., \& Redfield, P. (2011). Forces of compassion: Humanitarianism between ethics and politics. Santa Fe, NM: School for Advanced Research Press.

Coleman, M. (2007). Immigration geopolitics beyond the Mexico-US border. Antipode, 39(1), 54-76.

Coy, P. G. (2013). Co-optation. In D. Snow, D. della Porta, B. Klandermans, \& D. McAdam (Eds.), The WileyBlackwell encyclopedia of social and political movements. Hoboken, NJ: Blackwell Publishing.

Darling, J. (2014). Asylum and the post-political: Domopolitics, depoliticisation and acts of citizenship. Antipode, 46(1), 72-91.

De Genova, N. (2010). The deportation regime: Sovereignty, space, and the freedom of movement. In N. De Genova \& N. Peutz (Eds.), The deportation regime. Sovereignty, space and the freedom of movement 
(pp. 33-68). Durham, NC: Duke University Press.

Dean, M. (1996). Foucault, government and the enfolding of authority. In A. Barry, T. Osborne, \& N. Rose (Eds.), Foucault and political reason. Liberalism, neo-liberalism, and rationalities of government ( $\mathrm{pp}$. 209-230). Chicago, IL: University of Chicago Press.

Dean, M. (2010). Governmentality. Power and rule in modern society. London: Sage Publications.

Fassin, D. (2007). Humanitarianism as a politics of life. Public Culture, 19(3), 499-520.

Fassin, D. (2011). Policing borders, producing boundaries: The governmentality of immigration in dark times. Annual Review of Anthropology, 40, 213-226.

Fassin, D. (2012). Humanitarian reason: A moral history of the present. Berkeley, CA: University of California Press.

Fassin, D. (2016). From right to favor. The refugee question as moral crisis. The Nation. Retrieved from https://www.thenation.com/article/from-right-tofavor

Ferguson, J., \& Gupta, A. (2002). Spatializing states: Toward an ethnography of neoliberal governmentality. American Ethnologist, 29(4), 981-1002.

Fleischmann, L. (2017). The politics of helping refugees. Emerging meanings of political action around the German 'Summer of Welcome'. Mondi Migranti, 2017(3), 53-73.

Fleischmann, L., \& Steinhilper, E. (2017). The myth of apolitical volunteering for refugees: German welcome culture and a new dispositif of helping. Social Inclusion, 5(3), 17-27.

Foucault, M. (1982). The subject and power. In H. Dreyfus \& P. Rabinow (Eds.), Michel Foucault: Beyond structuralism and hermeneutics (pp. 208-226). Brighton: Harvester.

Foucault, M. (1988). Technologies of the self. In L. H. Martin, H. Gutman, \& P. H. Hutton (Eds.), Technologies of the self: A seminar with Michel Foucault (pp. 16-49). Amherst, MA: University of Massachusetts Press.

Hamann, U., \& Karakayali, S. (2016). Practicing Willkommenskultur: Migration and solidarity in Germany. Intersections. East European Journal of Society and Politics, 2(4), 69-86.

Heins, V. M., \& Unrau, C. (2018). Refugees welcome: Arrival gifts, reciprocity and the integration of forced migrants. Journal of International Political Theory, 14(2), 223-239.

Ilcan, S. (2014). Activist citizens and the politics of mobility in Osire refugee camp. In E. Isin \& P. Nyers (Eds.), Routledge handbook of global citizenship studies (pp. 186-195). Abingdon: Routledge.

Karakayali, S. (2019). The welcomers: How volunteers frame their commitment for refugess. In M. Feischmidt, L. Pries, \& C. Cantat (Eds.), Refugee protection and civil society in Europe (pp. 221-241). Basingstoke: Palgrave Macmillan.

Karakayali, S., \& Kleist, O. (2016). Strukturen und Motive der ehrenamtlichen Flüchtlingsarbeit (EFA) in
Deutschland, 2. Forschungsbericht: Ergebnisse einer explorativen Umfrage vom November/Dezember 2015 [Structres and motives of voluntary work with refugees in Germany. Second research report: Findings of an exploratory survey conducted in November/December 2015]. Berlin: Berlin Institute for Integration and Migration Research. Retrieved from https://www.bim.hu-berlin.de/ media/Studie_EFA2_BIM_11082016_V\%C3\%96.pdf

Keane, J. (2006). Civil society: Berlin perspectives. New York, NY: Berghahn Books.

Lemke, T. (2002). Foucault, governmentality, and critique. Rethinking Marxism, 14(3), 49-64.

Lessenich, S. (2011). Constructing the socialized self: Mobilization and control in the 'active society'. In U. Bröckling, S. Krasmann, \& T. Lemke (Eds.), Governmentality: Current issues and future challenges ( $\mathrm{pp}$. 304-320). New York, NY: Routledge.

Malkki, L. (1996). Speechless emissaries: Refugees, humanitarianism, and dehistoricization. Cultural Anthropology, 11(3), 377-404.

Malkki, L. (2015). The need to help: The domestic arts of international humanitarianism. Durham, NC: Duke University Press.

Mitchell, T. (1991). The limits of the state: Beyond statist approaches and their critics. The American Political Science Review, 85(1), 77-96.

Mountz, A. (2011). The enforcement archipelago: Detention, haunting, and asylum on islands. Politcal Geography, 30(3), 118-128.

Mountz, A., \& Hiemstra, N. (2014). Chaos and crisis: Dissecting the spatiotemporal logics of contemporary migrations and state practices. Annals of the Association of American Geographers, 104(2), 382-390.

Muehlebach, A. (2013). The catholicization of neoliberalism: On love and welfare in Lombardy, Italy. American Anthropologist, 115(3), 452-465.

Nützenadel, A., \& Strupp, C. (2007). Taxation, state, and civil society in Germany and the United States from the 18th to the 20th century. Baden-Baden: Nomos Verlag.

Nyers, P. (2006). Rethinking refugees: Beyond states of emergency. New York, NY: Routledge.

Nyers, P. (2010). Abject cosmopolitanism: The politics of protection in the anti-deportation movement. In N. De Genova \& N. Peutz (Eds.), The deportation regime. Sovereignty, space and the freedom of movement (pp. 413-442). Durham, NC: Duke University Press.

Pries, L. (2019). Introduction: Civil society and volunteering in the so-called refugee crisis of 2015: Ambiguities and structural tensions. In M. Feischmidt, L. Pries, \& C. Cantat (Eds.), Refugee protection and civil society in Europe (pp. 1-23). Basingstoke: Palgrave Macmillan.

Rajaram, P. K. (2002). Humanitarianism and representations of the refugee. Journal of Refugee Studies, 15(3), 247-264.

Rancière, J. (1998). Disagreement: Politics and philos- 
ophy. Minneapolis, MN: University of Minnesota Press.

Rancière, J. (2001). Ten theses on politics. Theory \& Event, 5(3). Retrieved from https://muse.jhu.edu/article/ 32639

Redfield, P. (2011). The impossible problem of neutrality. In E. Bornstein \& P. Redfield (Eds.), Forces of compassion: Humanitarianism between ethics and politics (pp. 53-70). Santa Fe, NM: School for Advanced Research Press.

Rose, N. (1996). Governing 'advanced' liberal democracies. In A. Barry, T. Osborne, \& N. Rose (Eds.), Foucault and political reason: Liberalism, neo-liberalism, and rationalities of government (pp. 37-64). Chicago, IL: The University of Chicago Press.

Staatsministerium-BW. (2015). Willkommen! Ein Handbuch für die ehrenamtliche Flüchtlingshilfe in BadenWürttemberg [Welcome! A handbook for voluntary help for refugees in Baden-Württemberg]. Stuttgart: Staatsministerium Baden-Württemberg.

Sutter, O. (2019). Narratives of "welcome culture". The cultural politics of voluntary aid for refugees. Narrative Culture, 6(1), 19-43.

Ticktin, M. (2006). Where ethics and politics meet: The violence of humanitarianism in France. American Eth- nologist, 33(1), 33-49.

Ticktin, M. (2011). Casualties of care: Immigration and the politics of humanitarianism in France. Berkeley, CA: University of California Press.

Ticktin, M. (2016). Thinking beyond humanitarian borders. Social Research: An International Quarterly, 83(2), 255-271.

Tyler, I., \& Marciniak, K. (2013). Immigrant protest: An introduction. Citiizenship Studies, 17(2), 143-156.

Vandevoordt, R. (2016). Between humanitarian assistance and migration management: On civil actors' role in voluntary return from Belgium. Journal of Ethnic and Migration Studies, 43(11), 1907-1922.

Vandevoordt, R., \& Verschraegen, G. (2019). Subversive humanitarianism and its challenges: Notes on the political ambiguities of civil refugee support. In M. Feischmidt, L. Pries, \& C. Cantat (Eds.), Refugee protection and civil society in Europe (pp. 101-128). Basingstoke: Palgrave Macmillan.

Walters, W. (2011). Foucault and frontiers: Notes on the birth of the humanitarian border. In U. Bröckling, S. Krasmann, \& T. Lemke (Eds.), Governmentality: Current issues and future challenges (pp. 138-164). New York, NY: Routledge.

\section{About the Author}

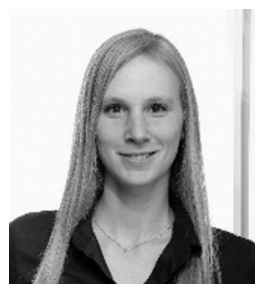

Larissa Fleischmann is a Postdoctoral researcher in the Department of Human Geography at the Martin Luther University Halle-Wittenberg in Germany. In early 2019, she completed her PhD on the contested solidarities of the German summer of welcome at the University of Konstanz, where she was a member of the Department of Social and Cultural Anthropology as well as the Centre of Excellence "Cultural Foundations of Social Integration" from 2014 to 2018. Her research interests include solidarity and political mobilisations in migration societies, refugee activism, and the anthropology of humanitarianism, amongst others. 